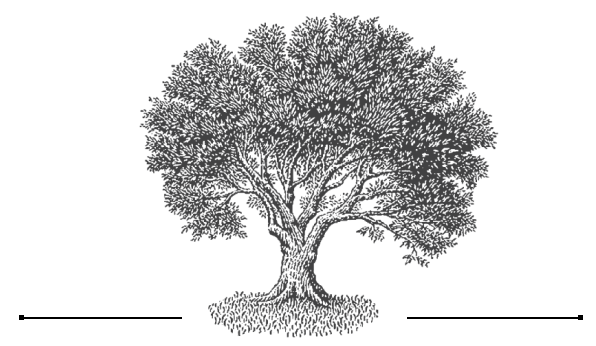

Preachers, Sermons, and State Authorities in late Baroque Dubrovnik*

\section{Relja Seferović}

Croatian Academy of Sciences and

Arts, Institute for Historical Sciences in

Dubrovnik

Dubrovnik, Republic of Croatia
Проповедники, проповеди и государственная

власть в

Дубровнике эпохи барокко

\section{Реля Сеферович}

Институт исторических наук

в Дубровнике Хорватской академии

наук и искусств

Дубровник, Республика Хорватия

\title{
Abstract
}

In order to keep its traditional neutrality in foreign policy and to preserve inner stability after the disastrous earthquake of 1667, the state authorities of the Republic of Dubrovnik controlled the entire public life in this city-state, which was clamped between Ottoman and Venetian possessions on the coast of the south Adriatic. They managed to impose their will on archbishops of the local Church in various aspects of religious life, including the election of public preachers in the city cathedral. Treated as simple officials in service of the government, these clerics (mostly members of various religious orders who came from Italy) played their role according to their employers' desires, with only formal concern for their flock. However, sermons by their local counter parts, who preached mostly in smaller city churches, left a deeper mark in this highly conservative Catholic milieu. An analysis of their experiences and preserved

* This paper was funded by the Croatian Science Foundation, as part of the project No. 5106 "Transformations of the Collective and Individual Identities in the Republic of Dubrovnik from the Late Middle Ages until the Nineteenth Century.” 
texts of their sermons offers a new perception of the political, social, linguistic, and even theological culture of late Baroque Dubrovnik, a city whose importance remained incomparable within the Slavonic world in the Mediterranean.

Keywords

Republic of Dubrovnik, Senate, Small Council, preachers, sermons, 18th century, archbishop, religious orders, cathedral

\section{Резюме}

После разрушительного землетрясения 1667 г. для сохранения внутренней стабильности и традиционного нейтралитета в международной политике органы государственной власти в Республике Дубровник контродировали всю общественную жизнь этого города-государства, зажатого между Оттоманской империей и венецианскими владениями на побережье южной Адриатики. Они смогди навязать свою водю архиепископам местной церкви в раздичных аспектах редигиозной жизни, в том числе в выборе проповедников городского собора. Рассматриваемые просто как доджностные дица на службе правительства, эти священники (в основном члены раздичных религиозных орденов родом из Италии) играли свою роль в соответствии с пожеланиями светских работодателей и только формально заботились о своей пастве. Напротив, проповеди их колиег, служивших преимущественно в небольших городских церквях, оставили куда больший след в своем глубоко консервативном катодическом окружении. Анадиз этих опытов и сохранившихся текстов проповедей демонстрируют нам новые способы понимания политической, социальной, языковой и даже богословской культуры позднебарочного Дубровника - города, чрезвычайно важного для всего славянского мира Средиземноморья.

Ключевые слова

Республика Дубровник, Сенат, Малый совет, проповедники, проповеди, XVIII век, архиепископ, религиозные ордены, собор

\section{The Public Manifestation of the Faith}

Holy mass, solemn procession, and pious sermon: within the frame of these three typical public manifestations of the faith, the sermon offers the quickest approach to both the secular and the spiritual culture of a society with a strongly developed rhetorical culture, as was the case for the former Republic of Dubrovnik/Ragusa. ${ }^{1}$ Lying on a narrow strip on the south-east Adriatic coast, deprived of natural resources, ${ }^{2}$ at the very edge of the Roman civilized world (as it was usually perceived), on the brink of the Ottoman Empire, and in constant threat from the Venetian Republic (with its numerous attempts

1 These bilingual forms of local names have remained in use almost until the present day.

2 Traditionally, the settlers preferred to live on the coast working as seamen and merchants rather than cultivating the sterile surrounding land [CERVA 2008: 273]. 
to re-establish its rule over this territory) ${ }^{3}$-as a result of all these factors, diplomacy in Dubrovnik was an absolute necessity for survival. Their opponents regarded Ragusans as humble servants and even spies who cared only for their own well-being and who managed to turn every crisis to their benefit, ${ }^{4}$ while, on the other hand, they tried to present themselves as gallant, devoted, and intrepid defenders of the Catholic Church across the Balkans. This is why rhetoric, in the form of secular speeches and ecclesiastical sermons, was such an important element in the public life of Dubrovnik, even in foreign and domestic policy. To approach this issue, a dedicated researcher may rely on the wealth of primary sources and commentaries, both in manuscripts and in published form. ${ }^{5}$

Religion played a very important role in the life of each individual; the Catholic faith was a part of the Ragusan identity. ${ }^{6}$ This was obvious both in private and in public matters. As an 18th-century local observer remarked, "Ragusan folk, especially patricians, are so pious that every morning, when they leave their homes, they go to church first and only after that do they turn themselves to their business and other duties" [CERVA 2008: 527]. ${ }^{7}$ The public manifestations of the faith served also to extol the inner political principles and values of the ruling class. Thus it is justified to remark that:

... all these occasions served as opportunities to stress the values of the nobility and the Republic. These rituals encouraged particular political and social ideas, and ensured mediation between the elite and the populace. It was important to unite the entire community by means of ceremony, since it assigned everyone their own position in the hierarchy [JANEKOVIĆ-RÖMER 2015: 414].

3 In 1205, "Dubrovnik had to accept Venetian supreme authority and in the course of [the] following 150 years remained the principal Venetian maritime base in the southern Adriatic area" [KREKIĆ 2007: 9]. Until the very end of the 18th century, the Serenissima never gave up its pretensions on Dubrovnik and its hinterlands.

4 These rumors were especially spread by the Venetians, even going so far as to accuse Ragusans of treachery regarding their dealings with the Ottoman Turks [KunČEvić 2012: 35-36].

5 Local historiography (with annals and biographical collections as predominant genres) was the most prolific source type in the Adriatic region, with the possible exception of Venetian historiography. In the absence of an appropriate monograph dedicated to this topic, an interested reader is advised to consult critical editions of various texts by Ragusan authors written in Latin or in Italian, mostly published by the Croatian Academy of Sciences and Arts.

6 With the exception of Catholics, only Jews were allowed to spend the night within the city walls. Although the Hebrew community had firmly established itself in Dubrovnik since the early 16th century, until the end of the Republic, in 1808, only Catholics enjoyed its full citizenship. Occasional attempts by the state authorities to accept non-Catholics as their equals were looked upon with scorn by members of the clergy [CERVA 2008: 512-513; SEFEROVIĆ 2012A: 134-146].

7 This is an echo of a thought by Philip de Diversis, a 15th-century Dubrovnik schoolmaster born in Tuscany, from his "Description of the Glorious City of Dubrovnik" [DE DIVERSIS 2004: 91, 174]. 
As one of the important means to preserve this hierarchy, preachers were carefully chosen, and they enjoyed various privileges in Dubrovnik, mercifully granted by the Senate, the supreme governing body in the state, which always kept them under close surveillance.

\section{How the Cathedral Preachers Were Elected}

Among the various duties of the Small Council, the main executive power in the state, was the election of public preachers in the cathedral at the beginning of every year. ${ }^{8}$ These preachers had to deliver sermons during the Advent and Lenten cycles before the Ragusan elite, because only patricians were permitted to follow the Divine service in the cathedral. The other city churches served for commoners and were in the hands of local preachers: the state authorities did not appoint them. According to the list of cathedral preachers from 1700 to 1800, the Small Council would usually engage the same preacher for Advent and Lent; only seldom were two separate preachers appointed. . Sometimes, in spite of meticulous preparation, it was necessary to improvise and find a suitable replacement, for example, when the invited preacher suddenly became unable to perform his duty, due to illness or other causes. ${ }^{10}$

This topic was often discussed during regular meetings of the Senate, especially concerning the remuneration of elected preachers, as well as different principles for their invitation, criteria that often changed over time, due to various interests of high political circles in the Republic. The government carefully observed how clerics behaved towards lay people in general; it independently chose and invited good preachers, demonstrating care that religious solemnities were always performed in the most successful way and that they completely fulfilled the spiritual needs of the people [SAMARDžIć 1983: 211]. The state authorities often interfered directly in Church affairs, even deciding about the times of holy masses both in the cathedral and in the church of

8 Although it was the main task of the Great Council, involving all Ragusan patricians, to elect the new dignitaries of the Republic at the beginning of every year, some duties were specifically under the purview of the Small Council, including the election of cathedral preachers.

9 I have established this list on the basis of various primary sources from the State Archives of Dubrovnik, especially from the conclusions by the Senate (Acta Consilii Rogatorum) and the Small Council of the Republic of Dubrovnik (Acta Consilii Minoris) [SEFEROVIĆ 2008: 117-119].

10 Augustinian friar Vincenzo Tei, in his letter in June 1796, informed the Ragusan Senate of his inability to come and preach because of a sciatica attack, causing him intolerable pain; in another instance, Dominican friar Vito Antonio Cavalloni, in 1774, changed his mind because he was offered a chair in theology at the Illyrian College in Loreto. Other preachers refused to come because of sudden duties in various monasteries in their religious orders across Italy. Capuchin friar Michelangelo Mitrovich refused the offer to preach in 1746, claiming that he needed more time to prepare [SEFERović 2008: 96-98]. 
St. Blaise (dedicated to the main Ragusan patron saint): the Small Council, from the end of 1737 until the beginning of 1741, rendered several decisions about this. ${ }^{11}$ However, they took special care regarding the sermons.

According to the regular procedure, at the first meeting of the Small Council following the public festivities in January, ${ }^{12}$ they would elect two patricians, usually members of the Small Council itself, to propose a preacher for two years in advance. They followed the same method regardless of the origin of the preacher, domestic or foreign. It seems, though, that this practice was established due to particular situations with respect to foreign preachers: as opposed to local clergymen, many foreigners were professionals who were compelled to plan their preaching tours for several years in advance, so it was important to approach them in time, in order to persuade them to come. ${ }^{13}$

The decision of two electors in the Small Council about the would-be preachers had to be approved at a separate session of the Senate, and by a majority of two-thirds. This practice did not change even after the disastrous earthquake of 6 April 1667, ${ }^{14}$ and it was regularly observed until the end of the Republic in the early 19th century. However, the approval by the Senate was a mere formality, because many members of the Senate were also members of the Small Council.

In the period after the Great Earthquake, it happened only once that electors did not reach a mutual agreement on the would-be preacher in the cathedral: in 1721, three candidates were proposed to the Small Council and its members decided by vote who would preach in 1723 [Cons. Min., Vol. 90, F. 264v-265r]. An irregularity also occurred in 1763, when, due to a clash among powerful patrician clans, two electors were appointed only at the beginning of March. ${ }^{15}$ In all other cases, electors performed their duty in time and in mutual accord.

The first appointment of the electors by the Small Council after the Great Earthquake happened in January 1668, when they chose a preacher for 1670:

${ }^{11}$ The cathedral was destroyed in the Great Earthquake in 1667, and until its restoration and consecration in 1713, the church of St. Blaise served as its replacement. When this church was destroyed by fire in 1706 , it was the Dominican church that temporarily replaced the cathedral.

${ }^{12}$ The list of public festivities in the Republic of Dubrovnik by the middle of the 18th century has been analyzed by both Ragusan classical and contemporary historians [CERVA 2008: 444-448; LONZA 2009: 387-399].

${ }^{13}$ In his letter from Rome in 1768, Jesuit Aurelio Maria Rezzonico politely declined the invitation to preach in Dubrovnik, saying that he was engaged for eleven years in advance, thus setting the record for advanced bookings [SEFERović 2008: 98].

${ }^{14}$ Poetically described as "the first death of the city" [Vojnović 1912: 52-69], in this tragedy nearly two thousand people, or more than one-third of the city's inhabitants, lost their lives [VEKARIĆ 2011: 271-273].

${ }_{15}$ An open clash within patriciate ranks by the end of 1762 and at the beginning of 1763 produced a four-month stalemate within the government [ĆOsIć, VeKARIĆ 2005: 89]. 
this was Dominican friar Hyacinth Maria Passati, a local man who later became bishop of the Diocese of Ston, one of the two suffragan bishoprics in the Dubrovnik Metropolitan Church [CERVA 1977: 156-157]. Since the first regular election of the city rector after the Great Earthquake happened only at the beginning of May 1669 [SAMARDžIć 1960: 441], it was obviously more important to re-establish the line of the Advent and Lenten preaching cycles in order to regain stability than to re-establish the formal political order in the Republic.

Among the preachers who were invited to give sermons during Advent and Lent, there is absolute domination of members of various religious orders; only on rare occasions were members of the lay clergy appointed. This may have been caused by two reasons: by the desire to employ a respected preacher with good connections abroad (thus contributing to the prestige of the Republic in wide circles), and by the desire to avoid an independent critic from their own political environment, which would be a figure difficult to control. ${ }^{16}$ Nevertheless, exceptions were made from time to time. A distinguished name among lay clergymen was Canon Stephanus Rosa, a member of the chapter of the Ragusan Church, who ascended to the cathedral pulpit three times during the 18th century [CERVA 1980: 127; SEFEROVIĆ 2008: 118]. The guest from the island of Korčula, which was under Venetian political control, Canon Jakob Arneri, was invited once, and another canon from Dubrovnik, Jeronim Bona, also preached on one occasion in the cathedral, during Lent [SEFERović 2008: $87-88,104,118]$. They did not leave a deeper mark in the long line of their preacher colleagues, apparently serving only as a sort of intermezzo until the tradition of monks and friars as preachers in the cathedral was re-established.

Members of various religious orders were regularly invited to preach in the cathedral. Over the course of the 18th century, Franciscans (either from the Observant or from the Capuchin branch of the order) were the most popular preachers in the Dubrovnik cathedral: they were elected thirty-five times, whereas Dominicans were elected seventeen times to address the Ragusan patriciate from the cathedral pulpit [SEFERović 2008: 117-119]. Contrary to the established practice in the rector's chapel (where only Franciscan and Dominican preachers performed holy services), members of other religious orders, such as Benedictines, Barnabites, Theatines, and Augustinians, also came to preach from the pulpit of the Ragusan cathedral. However, these orders were represented only until the beginning of the 18th century, and

16 While all religious orders were regularly compelled to turn to state officials for various kinds of material help, especially during the long reconstruction of their churches and monasteries after the Great Earthquake, diocesan clerics enjoyed a higher level of independence, thanks to their fraternity of priests, St. Peter's Chair in Antioch, which the state authorities were unable to subdue [LASIĆ 2001: 695-699; SEFEROVIĆ 2012A: 125-134]. 
between 1700 and 1800, there were only a few Jesuits and Piarists (their direct successors in Dubrovnik, after the temporary suppression of the Jesuit order in 1773) [IDEM 2015: 313] who interrupted the long sequence of preachers coming from the two most prominent mendicant orders.

Preachers in the cathedral delivered their sermons three times a week in Advent and in Lent. This tempo was officially confirmed by the decree of the Small Council in 1729 [Cons. Rog., Vol. 154, F. 94v-96r]' but it was also the case in previous years: during the plague epidemic in 1691, Jesuit Ardelio Della Bella also preached three times a week [SEFERović 2008: 86]. The Small Council intervened on another important matter: due to some bad experiences with foreign preachers, they changed the law in 1729, deciding that subsequently, only subjects of the Republic of Dubrovnik were to be elected cathedral preachers. ${ }^{17}$

Yet this practice did not last for long. Up to the end of the 18th and the beginning of the 19th centuries, no further limitations were imposed on foreign preachers. On the contrary, at the beginning of April 1782, the Senate issued a new law on cathedral preachers for Advent and Lent [Cons. Rog., Vol. 190, F. $78 \mathrm{r}-78 \mathrm{v}]$, reducing their income and deciding that local clerics could not preach in the cathedral unless they were elected by a two-thirds majority in the Senate. In spite of this decision, domestic preachers remained predominant, but this was due to other reasons, especially the great political crisis both in the Apennines and in Dubrovnik after the escalation of the Napoleonic wars, when some distinguished foreign preachers were compelled to decline the invitation from Dubrovnik. ${ }^{18}$

What they actually missed becomes obvious from a formal letter of invitation, written in Italian by the Small Council to an unknown preacher:

To the Most Reverend Father: the news we received from many parts about the talents God has bestowed on you in service of apostolic preaching motivates us to engage you to the benefit of our homeland. We are therefore pleased to have decided to invite you to preach from the pulpit of our cathedral during Advent and the subsequent Lent. We let you know about our decision so that you can arrange your matters and be with us in time, to answer our call and perform your duty with the benefice to the souls and in accordance with the public wish [Lettere di ponente, Vol. 49, f. 231r].

These expressions were suitable for domestic and foreign preachers, as well as for members of the diocesan clergy and various religious orders who were

17 “... omnes illi qui in posterum essent nominati... pro concionatore nostrae ecclesiae cathedralis non possint esse nisi nationales" [Cons. Rog., Vol. 154, f. 95v].

18 At the end of the 18th century, Jesuit Stefano Antonio Morcelli even turned down an official offer to become the Ragusan archbishop because he preferred to stay in his native Brescia and help his flock, which was in peril due to the imminent French invasion [SEFEROVIĆ 2016A: 279-280]. 
honored by the invitation to address the Ragusan public. The letters of invitation were usually sent either to Ragusan diplomatic representatives in Rome (asking them to find a suitable preacher there), or to generals of the chosen religious orders, with the same request, that is, to send an appropriate preacher to Dubrovnik. In both cases the preachers were supposed to be highly respected persons of advanced age, with adequate previous experience and perfect behavior. This request, however, would occasionally cause serious trouble to skillful Ragusan diplomats, as it was often impossible to find an appropriate person in a relatively brief period of time. In the middle of the 18th century, for example, ambassador Benedikt Stay openly complained in a letter to his superiors in Dubrovnik that "all the good preachers, and even the average ones, were already engaged, and it was hardly possible in September to find someone to preach in Dubrovnik during Lent" [Acta et Diplomata, Vol. 16, Doc. No. 2048]. So, to put it simply, even in Rome it was hardly possible in only six months to find a good and reliable preacher, one who was willing to take this challenge and cross the Adriatic Sea to Dubrovnik. On the other hand, it happened on a few occasions that foreign preachers approached Ragusan representatives in Italy to ask them personally if they could provide them with recommendations to preach in the cathedral. In spite of the fact that some of them were recommended by illustrious people such as Roman cardinals themselves, ${ }^{19}$ the Ragusan government remained suspicious and preferred to make its own choice on all occasions.

The most popular individual preachers were two domestic men: the Franciscan friar Sebastian Slade Dolci was invited to preach seven times between 1729 and 1771, thus setting the record for the greatest number of invitations, and the Benedictine monk Ludovico Moreno preached six times between 1709 and 1725 [SEFEROVIĆ 2008: 117-118]. ${ }^{20}$ What put them above the others was the fact that they were both employed by the state as official advisers in theological matters; as the so-called teologi di Stato, they proved themselves to be reliable and educated civil servants who successfully performed the delicate duty of preaching in the cathedral [IDEM 2010: 249-251].

Apart from their experience and good manners, preachers were expected to avoid any sensitive political points in their sermons; they were not permitted to negotiate on material conditions offered by the Ragusan government; and they were not to be Venetian subjects. A long-standing Ragusan distrust of Venice, originating from the middle of the 14th century, when they overthrew the Venetian rector and started on the long path toward becoming an independent

${ }_{19}$ Cardinal Nicholas Radulović, in 1701, praised his former secretary, Francesco Ruggieri, very highly, even recommending that he become the official Ragusan envoy at the Holy See in Rome [Acta et diplomata, Vol. 1, doc. No. 4].

${ }^{20}$ Moreno was an Italian by birth but he spent decades living in Dubrovnik, and enjoyed a great deal of respect for his loyalty [SLADE 2001: 120, 222]. 
city-state [JANEKOVIĆ-RÖMER 2003: 87], was present in ecclesiastical matters, too. As Ragusan archbishops were not permitted to be Venetian subjects, this was obviously also a condicio sine qua non for other members of the clergy. There were only two exceptions noted in this period: the Dominican friar Cherubin Veci, from the island of Hvar (not far from the city of Split), was invited to preach at the Dubrovnik cathedral in 1708, and Jakob Arneri, from the nearby island of Korčula, delivered his sermons in Advent of 1739 and in the subsequent Lent of 1740 [SEFEROvić 2008: 87-88, 118]. Their engagement may be explained in light of certain commercial interests of the Republic of Dubrovnik with respect to the middle Dalmatian islands during that time.

Political interests definitely played a role in the election and appointment of preachers in the cathedral, but its impact was less visible in other places of public worship in the city.

\section{Other Places of Public Worship}

From the second half of the 17th century until the early 19th century, the main city churches where sermons were delivered were the cathedral and the Dominican, Franciscan, and Jesuit churches, as there were no typical parish churches in the city. ${ }^{21}$ There was a delicate balance among these churches, and any disturbance would have caused serious trouble: when Archbishop Andrea de Robertis imprudently excommunicated Dominican friars in Dubrovnik and forbade holy services in their church after some incidents in 1709 , the state authorities immediately sent a complaint to the pope, explaining that local people were left almost without a place to worship, and that the Franciscan church could not possibly accept all of them while the cathedral was still under construction and renovation after the Great Earthquake [SEFEROvić 2012A: 26-34]. In spite of the proverbial rivalry among the two mendicant orders, the Dominicans and Franciscans traditionally maintained good mutual relations in Dubrovnik, and they also collaborated in preaching. They respected the old custom of exchanging visits on the feasts of their founders, with Dominicans preaching at the Franciscan church on St. Francis' Day and the Franciscan friars reciprocating by visiting the Dominican church on St. Dominic's and St. Thomas Aquinas' feasts [Monumenta congregationis: 160-161].

The Dominicans and Franciscans also preached in open places, for example, in the city loggia near the church of St. Blaise, where they were active three times a week during Lent, in alternation [Monumenta congregationis: $152-154]$. In the second half of the 18th century, the Jesuits introduced some

${ }^{21}$ In spite of requirements issued by the Council of Trent, and regardless of several attempts by Ragusan archbishops from the second half of the 16th century on, it was only by the end of the 18th century that separate parishes were finally established in the city [SEFEROVIĆ 2012B: 128-130]. 
new places for preaching, mostly at the initiative of their prominent member Bernardo Zuzzeri. He became very influential after his sermons in the Jesuit church, which were given every Sunday in front of the pious confraternity of Bonae Mortis (Good Death), gathering both patricians and commoners [BAŠIć 1872: XIV]. Zuzzeri apparently was so convincing that he won the trust of the state authorities, who, in 1734, asked for his help in providing Lenten sermons in the cathedral as a replacement for an invited and previously announced preacher who had failed to appear. Although he had very little time to prepare, Zuzzeri successfully improvised. As a skillful orator, he knew how to use the same sermons on different occasions (with slight changes), and he even managed to reduce his appearances to only twice a week [IBID.]. It was also due to Zuzzeri's merit that preachers began to visit churches outside the city walls. He personally established a preaching cycle in the church of Our Lady of Mercy, located on the nearby peninsula of Lapad (some $5 \mathrm{~km}$ away from the city walls), where he used to preach every Saturday during Lent [IBID.].

There was a special case regarding preaching in the rector's chapel, which was located in the Rector's Palace. Since the new rector was regularly elected every month, according to century-long practice in Dubrovnik [CERVA 2008: 311-312], it was at his own discretion to invite either Dominican or Franciscan friars to preach during the period of his rule. They were appointed according to the family traditions of the rector: patrician families had their graves in the churches of one of these two monasteries. The salary of these preachers was always covered from a special rector's treasury. ${ }^{22}$

Apart from these preachers in the rector's chapel, it seems that only cathedral preachers in Dubrovnik received regular income for their services, as such payment had been prescribed by the Senate: whereas foreign preachers were paid 250 ducats for their efforts, local men never received more than 150 ducats [Seferović 2008: 86-87]. ${ }^{23}$ Domestic preachers who delivered their sermons in other city churches were not entitled to any income. All rewards they received from their flock had to be used for their monasteries. ${ }^{24}$ Obviously, this situation was not very favorable for domestic preachers, but they were able to compensate for this loss in their own preaching tours abroad, far away from the borders and control of the Ragusan Republic.

${ }^{22}$ From the second half of the 17th century to the beginning of the 19th century, their income remained the same, two grossi per day. In the early 19th century, this was the price of a chicken egg at the public market in the city [Detta, Vol. 90, f. 14r, 15v, 34r].

${ }^{23}$ In comparison, at the beginning of the 18th century, the official diplomatic representative of the Republic of Dubrovnik in Rome earned 100 ducats per year [SEFEROVIĆ 2012A: 19], while the bishop of Ston, in the middle of the 18th century, received only 80 ducats per year from the state authorities [IBID.: 76].

${ }^{24}$ When high ecclesiastical officials, such as archbishops or archpresbyters, delivered short sermons after solemn masses on various feasts, they would receive a significant financial reward from the state authorities, up to 40 grossi [Detta, passim]. 


\section{Ragusan Preachers Abroad}

Although Venetian subjects were never warmly greeted in Dubrovnik, things functioned quite well in the opposite direction, and there were many Ragusan preachers who performed their holy service in various cities under Venetian political control. This occurred not only in nearby Kotor (which was an especially common destination for Franciscan friars coming from various monasteries of St. Francis' Province in Dubrovnik) [SOPTA 2006: 84], but also in Split (some $220 \mathrm{~km}$ away), where Dominican friar Albert a Thaddeis was praised for his sermons in the cathedral at the end of the 17th century [CERVA 1975: 30-31].

Other distinguished preachers from Dubrovnik, for example, the Franciscan friar Sebastian Slade Dolci, the canon Stephanus Rosa, and the Jesuit Bernardo Zuzzeri, all mentioned above, preached on a number of occasions not only in Venetian Dalmatia, but also in Habsburg lands and in various cities across the Apennines [SEFERović 2008: 105]. Under the title Memoria dei pulpiti occupati dallo stesso P. Dolci, Friar Dolci proudly presented a long list of pulpits where he preached the word of God over a span of 22 years (1723-1745): from cities on the coast of the Istrian Peninsula (Isola/Izola, Parenzo/Poreč, Rovigno/Rovinj, Pirano/Piran, Grado/Gradež), to the most important centers across the Apennines, including Sinigaglia (famous for its fair, where Ragusan merchants were regular customers), Florence, Naples, and Rome (Dolci must have reached the pinnacle of his career while preaching at Ara Coeli, the main Franciscan monastery in Rome) [Orationes Latinae: 174-175].

It appears as if foreign powers were less suspicious than the Republic of Ragusa with respect to their preachers, but the truth is that nearby regions were far behind Dubrovnik in terms of the level of their economic development. Since the local people in Dalmatia lived in poor conditions, preachers simply educated them through their sermons, while in relatively rich Dubrovnik, preachers had other interests, sometimes in direct conflict with the wishes of their seemingly humble public [SEFERović 2008: 113]. Besides, the successful tours of Ragusan preachers across the Apennines may be attributed to the fact that they had studied theology at various Italian universities, for example, Naples and Padua, and had gotten their first experiences as preachers addressing that public [IDEM 2012A: 217-224; IDEM 2013: 90, 96, 99-102]. Undoubtedly, they enjoyed more liberty there than at home.

\section{The Influence of the Senate over the Role of the Archbishop}

Apart from their "correct" political adherence, public preachers had to accept other conditions imposed by the government. These conditions were, above all, connected to their material rights (especially their salary), but also to their status in Dubrovnik in general. During the 18th century, there were several 
concrete legal steps issued by the authorities of the Republic to regulate the position of the Advent and Lenten preachers in the cathedral. Although formally it was the archbishop's blessing that determined who would preach from the most prestigious city pulpit, it was in fact the Senate that made the final call. Besides, due to the archbishopric's low income and relative poverty in general [SEFEROVIĆ 2012A: 41-55], the state took charge of all the major financial issues of the Ragusan Church.

It is obvious that the archbishops were never seriously consulted on these matters. Their opinion was only formally relevant ${ }^{25}$ However, there were some occasions when the would-be cathedral preacher did not have even their formal support, and when archbishops tried to impose their opinion against the government's wishes, even looking for papal support for their views. This happened when archbishops were personally offended by the public preachers in the cathedral, or when they openly protested against blatant violations of ecclesiastical immunity. At the end of the 17th century, Archbishop Placido Scoppa excommunicated the preacher Ottavio Bonamici, a Celestine monk. Scoppa was offended by one sermon delivered by this foreign friar, and forbade him from continuing to preach in the cathedral [SEFEROVIĆ 2012A: 23]. The next such case occurred in 1717, when another dissatisfied archbishop, Giovanni Battista Conventati, cancelled his permission to Benedictine monk Ludovico Moreno to preach during Lent. This happened because the archbishop rejected an opinion about ecclesiastical immunity issued by Moreno, who was acting in his position as official adviser to the state in theological matters. The Senate had to make a great effort, asking through diplomatic channels for papal intervention, in order to hear sermons from one of its favorite preachers [IDEM 2010: 250].

Although the Holy See supported the views of the Senate on both occasions and permitted preachers to continue with their duties, this was not the case in 1704, when, upon the intervention of the Holy See, a local cleric was denied the right to preach in the cathedral. The problem arose because the Small Council appointed, and the Senate approved, as the cathedral preacher Vincent Lupis, a cleric who at that moment was the bishop of Ston. According to high ecclesiastical dignitaries, he was not supposed to preach outside his own diocese, notwithstanding the fact that his bishopric was very small. ${ }^{26}$

25 Apart from the low income and poverty of the archbishopric, we may search for an explanation also in the fact that Ragusan archbishops from 1362 until 1722 were always foreign prelates, who very seldom personally came to the city. Although the situation changed in 1722, from which time until the end of the Republic all the archbishops were domestic people who actually lived in the city, their influence remained irrelevant.

26 On this occasion, the state authorities had to accept a harsh response from Rome: "If there are just ten men in his own diocese, let him preach to these ten!" [SEFEROVIĆ 2008: 92]. 
However, less than half a century later this was forgotten, and the Dominican friar Hyacinth Maria Milković, again as the bishop of Ston, was appointed to preach in the cathedral of Dubrovnik. He even received 400 ducats from the Senate on 8 April 1747, both as a reward for his sermons in Advent and Lent and as additional financial support for his bishopric [Cons. Min., Vol. 96, f. 92r]. In brief, the state authorities enjoyed almost absolute freedom in their election of preachers, and the role of the church authorities was usually reduced only to formal acceptance of the imposed solutions.

\section{The Arrival of Foreign Preachers and Their Sojourn in the City}

In contrast to the practice of itinerant preachers, who in earlier periods made occasional visits to Dubrovnik, either on their way to adjacent lands or simply in pilgrimage, ${ }^{27}$ at least from the late 17th until the beginning of the 19th century, all visits of foreign preachers were carefully planned by the government of the Republic. Upon acceptance of the formal invitation, the chosen preacher would receive further instructions about how to reach this distant city. He would embark on a ship under the flag of St. Blaise, usually in the ports of Ancona, Venice, or Naples, entrusting Ragusan captains for his safety. Not all of these preachers were willing to do so: on a number of occasions, among the reasons for turning down this offer from Dubrovnik were complaints of the long and hard journey across the sea [SEFEROVIĆ 2008: 94, 96]. However, such problems were soon forgotten upon their entrance into the city.

Sometimes arriving in the company of fellow clergymen, foreign preachers enjoyed several advantages in comparison to their domestic counterparts, with more liberty and significantly better material conditions. Since all their expenses were covered from public sources, ${ }^{28}$ their finances were meticulously described in the records, and we can follow them closely. Already in 1672, only five years after the Great Earthquake, while the city was still under reconstruction, there was a precise description, informing us even about the wages of various Ragusan workmen for their services in the context of the visiting preacher. While almost the whole city was in ruins, it was necessary to provide the preacher with a suitable home for the several months he was going to spend in Dubrovnik. Additional expenses were needed to prepare his dwelling place. For this purpose some private houses were taken for rent and various refurbishments were paid for (new furniture and furnaces were brought in,

${ }^{27}$ Apart from legends about the arrival of St. Francis himself [ŠKUNCA 2010: 17; Roščić 2012: 34], it is important to mention in this context the Franciscan friar Tommaso from Osimo, who roused many spirits among Ragusans during his brief visit in 1515 [SEFEROVIĆ 2014: 71].

${ }^{28}$ Their expenses officially came from the rector's own purse, and they were later covered from public means, according to decisions made by the Small Council and later approved by the Senate [Detta, passim]. 
sometimes even doors had to be repaired). The state authorities had also to settle the account with the captain of the ship that brought the preacher to the port of Gruž, approximately $5 \mathrm{~km}$ from the city itself, and to pay the soldiers who carried the preacher in a litter and provided him with a solemn escort during his stay in the city. ${ }^{29}$

It was natural to expect some help from various religious orders with the preachers' accommodations: they were supposed to accept their brethren coming from abroad in their appropriate monasteries. However, problems would appear when preachers were members of religious orders that did not exist in Dubrovnik (only Benedictines, Dominicans, Franciscans, and Jesuits, later replaced by Piarists, had their houses in the city). It was under such circumstances that local friars would not show their hospitality: at the end of 1751, for example, the Carmelite friar Gasparo de Santa Anna, from Milan, was rejected when he turned to the Jesuits, asking them to accept him in their College during his stay in Dubrovnik. They replied simply that his sojourn of six months was too long. When he afterwards turned to the Dominican friars, asking for the same favor, he was rejected again, with the same excuse. It was only upon the intervention of the Small Council that the Dominicans finally permitted him to stay in their monastery [SEFERović 2012A: 185].

In spite of these unpleasant experiences, foreign preachers mostly carried very favorable impressions from Dubrovnik. It was quite common, upon their return to Italy, to send complimentary letters to their former hosts, expressing their gratitude for their invitation and hospitality. For example, in his letter to the Ragusan Senate from Genoa in April 1716, Jesuit Giovanni Battista Cancellotti mentioned with pride that he praised Dubrovnik wherever he went, to the extent that others even began to believe that he was a Ragusan subject [Acta et diplomata, Vol. 7, Doc. No. 953]. Similarly, the Carmelite friar Gasparo de Santa Anna assured the Senate in 1752 that he would never stop offering his prayers to the Lord for the conservation and salvation of the Ragusan Republic [SEFEROVIĆ 2008: 99]. Occasionally, even generals of religious orders wrote similar letters, promising the Republic their good will and their inclination and readiness to help: no doubt this was motivated by their intentions to preserve and support members of their religious orders under Ragusan political control. ${ }^{30}$ It was important also for Ragusan authorities to maintain their good

29 The same service was offered to other high dignitaries: the public physician, controllers of various public works, and members of the government of the Republic [Detta, passim].

${ }^{30}$ For example, Friar Bernardo di Saluzzo, general master of the Franciscan Order of Capuchins, sent a complimentary letter to the rector and Small Council of the Republic of Dubrovnik at the end of June 1702, to express his gratitude because they were so pleased with sermons delivered by the Capuchin friar he had sent to Dubrovnik, Ansovino da Camerino [SEFEROvić 2008: 99]. 
name and prestige among the foreign preachers, educated and respected men who traveled a lot and who could have further contributed to Ragusan glory in important circles simply by talking about it. Some preachers, indeed, developed a genuine interest in the city and its inhabitants, spreading news about them, for example, about the astronomer and mathematician Vincentius Poz$\mathrm{za}$, from the middle of the 17th century, "whose fame spread almost across all of Italy, thanks to churchmen who used to come every year to Dubrovnik to give their sermons" [CERVA 1980: 190].

It cannot escape our notice that preachers always received gifts in material goods from the Senate. During their stay in Dubrovnik they enjoyed various delicacies such as lamb, chocolate, sugar, good fish, shellfish, and wine; gifts from the Renaissance period included luxury goods such as expensive clothes, carpets, and even weapons [SEFEROvić 2016B: 199-200]. They were never offered (and apparently never asked for) books and manuscripts; they never seriously bothered to improve the lives of their brethren from the same religious orders who were living in the territory of the Republic of Dubrovnik; and they never refused financial awards (currently, we know of only one case when a foreign preacher refused the financial reward for himself, instead passing the money on to his religious order: Capuchin friar Ansovino da Camerino in 1702) [SEFEROVIĆ 2008: 99]. This was simply how professionals behaved: their task was only to preach and to perform this duty in an efficient manner, without any genuine emotions. Their public expected nothing else-sermons were just an outer, public confirmation of the faith, and it mattered only how one performed this ritual. This was the case with the patricians who gathered in the cathedral, whereas commoners in other churches showed deeper feelings and more devotion, perhaps because foreign preachers hardly ever crossed their doorstep. For patricians, as the ruling class, it was necessary not to disturb the balance, but sometimes this did happen.

\section{The Address of Preachers to the Public}

Cari signori, ascoltanti, uditori, signori riveritissimi, uditori miei cari..${ }^{31}$ These expressions were often heard from the cathedral pulpit during sermons in Italian. However, even in this late period it was not uncommon to deliver a sermon in Latin. At least two cases have been preserved, both by Ragusan patricians who addressed the public in the cathedral: Lucas Gozze in his sermon on Christ's sufferings, De internis Christi morientis cruciatibus oratio in 1799 and Natalis Saraca in 1800, in his sermon on Christ's Passion, De

31 "Dear gentlemen, hearers, listeners, most honorable gentlemen, my dear listeners," taken as an incipit of various sermons gathered in collections in the late 18th and 19th centuries, but mostly copied from originals dating from earlier times [Predica: 8]. 
Passione Christi Oratio. ${ }^{32}$ On both occasions the archbishop was also present, and they addressed him at the beginning, greeting him before the members of the Senate and other distinguished patricians: Praesul amplissime, P. [atres] C. [onscripti] vosque omnes ornatissimi auditores.

On the basis of copies of sermons delivered in the cathedral and in other churches in Dubrovnik, it is possible to estimate that sermons lasted for approximately one hour. While an anonymous preacher mentioned specifically that it was his intention to spend just half an hour, mezz'oretta [Sermoni di passione: 277], with his flock, sermons were usually longer, as they contain sixteen-twenty pages in manuscript. ${ }^{33}$ Laudatory or funeral speeches, given at the same time in the cathedral in honor of deceased dignitaries of the Republic, both secular and ecclesiastical, also lasted up to forty-five minutes [SEFEROVIĆ 2012B: 121]. City fathers were apparently too impatient to hold out any longer: this is yet another proof that the sermons in the cathedral served only to fulfill an expectation, answering only a formal need. If we take into account published sermons delivered by the Dominican friar Archangel Kalić and by the Jesuit Zuzzeri in the late 18th century, it appears that sermons lasted longer in smaller churches. By preaching in their native language, the speakers managed to attract their listeners' attention for a longer period, and, judging by the reactions of their public, they were more successful than the refined preachers in the cathedral.

The Republic of Dubrovnik was a multilingual environment par excellence: this city-state of merchants and diplomats skillfully used a variety of languages, receiving praise from many impressed foreigners because of this talent [SEFEROVIĆ 2012A: 16-17; CERVA 2012: 356]. In 1783 Latin was formally replaced by Italian as the official language of public documents [Ćosić 1996: 138], although it was still used in the records of the Small Councilis and occasionally in official correspondence (especially in letters addressed to the papacy). However, in public sermons in this period only two languages were used: Italian in the cathedral and the local Slavic idiom in other churches. This practice is known not only from the preserved texts of sermons, but also from various eulogies. ${ }^{35}$ This environment was thus favorable for Italian preachers,

32 Both solemn speeches were preserved in a manuscript in the Scientific Library of Dubrovnik, No. 839.

33 This is according to various collections of sermons kept in the library of the St. Francis' Monastery in Dubrovnik [Sermoni di passione] and in the Scientific Library of Dubrovnik [Predica].

34 This practice, of writing decisions of the Small Council in Latin, remained until the end of the Republic.

${ }^{35}$ Dozens of similar speeches have been preserved in 19th-century copies. These collections have been kept in the libraries of the St. Francis' Monastery [BRLEK 1952: $219,241]$, but also in the St. Dominic's Monastery and in the Scientific Library in Dubrovnik. 
who could easily perform their duties at the Dubrovnik cathedral speaking in their native language. In the words of a connoisseur of the local circumstances, who wished to compliment Ragusans,

almost all of them speak Italian excellently because of their connections with Italy, from which place every year they bring a distinguished preacher at significant expense to preach for Advent and Lent in their cathedral, although they have many good preachers who preach in their native language surprisingly well [CERVA 2012: 356].

Apparently, this practice survived from earlier times. Another newcomer to Dubrovnik from the Apennine Peninsula, Dominican friar Serafino Razzi, who from 1584 to 1587 performed important duties both in the Dominican Province in the city and as a high ecclesiastical dignitary in the archbishopric, noticed the following peculiarities about sermons delivered in the cathedral: "... they always preach in Italian in the cathedral. The Ragusan patricians keep this custom, among other reasons, also to show that they originate from Roman, Italian blood" [RAzZI 2011: 157].

Apart from his obvious attempt to contribute to the old city legends about the ancient Roman origins of the Ragusan patriciate, legends that were common along Dalmatian shores and very popular among other writers as well, ${ }^{36}$ Razzi's words bring our attention to the social role of the preachers. Commoners were not allowed to enter the cathedral:; ${ }^{37}$ sermons were designed only for the patricians. However, in other city churches the public was mixed: patricians were, of course, always free to attend the Divine service, but commoners were the main public to whom sermons were directed. This fact also influenced the contents of the sermons. While it was common to preach in the cathedral about some abstract theological points, carefully avoiding anything that would rouse political suspicion, ${ }^{38}$ preachers in other churches often used their position to point out some common evils in the society, such as usury or prodigality.

36 The story of the legendary King Pavlimir-Bel created a lasting inspiration for generations of historians from Dubrovnik and adjacent regions. In this legend, the king was said to have come from Rome and established Dubrovnik's public life on new grounds, founding the Senate from among his men who followed him from Rome and from inhabitants of the ancient Roman colony of Epidaurus, some $20 \mathrm{~km}$ east of Dubrovnik [CERVA 2008: 272-280; SEFEROVIĆ 2011: 133-178].

37 There may have been exceptions related to hearing confessions before some great feast days, such as Easter. On other occasions, it was extremely rare to permit commoners to enter the cathedral, which might occur, for example, during some public disputes among members of the clergy [SEFEROVIĆ 2014: 57-59].

38 The situation in 1763 was typical: members of the Small Council postponed the election of the cathedral preacher for two months, and Jesuits even skipped the sermons in their church, being afraid that some expressions might be "misunderstood" [SEFERović 2008: 90-91]. 
Local preachers, born in Dubrovnik, were well aware of all the hidden deficiencies of their compatriots whom they were free to address in their native language, and they were very successful in their work, leaving much stronger impressions than their colleagues, who were engaged for quite expensive means in the cathedral. Outside the city the situation was even worse: poor priests who served in almost ruined churches in remote villages near the Ottoman border or on quite distant islands were hardly motivated to fulfill their pastoral duties, especially for preaching. They occasionally received some help from Jesuit missionaries. Several written reports convince us of good receptions by the flock, including mass peace offerings and greetings to the preachers at the beginning of their sermons [VANINo 1987: 115-131]. However, archbishops were justifiably dissatisfied with this situation, and they tried in vain to improve it. In spite of their efforts to increase the discipline of local priests, ${ }^{39}$ there is a convincing opinion by Archbishop Raimond Gallani, who noted in a letter to Rome, after his official visitation of the diocese in 1724, that many priests accepted their appointments in distant villages almost as punishment [SEFEROVIĆ 2012A: 61]. As a result, the flock remained poor and uneducated.

This last characteristic was shared in the city itself by women. It was a common opinion that patrician women were uneducated and that they understood only their native language, ${ }^{40}$ while women of the class of commoners were in much worse condition, and occasionally provoked jest even from their friars and confessors.$^{41}$ Nuns were in a particular position: nobody was allowed to preach in convents without the previous consent of the archbishop. This was again related to the wishes of the state authorities: they jealously kept convents under direct control, because these monasteries mostly gathered daughters from patrician families [SEFEROVIĆ 2012A: 97-117, 148-149; CERVA 2012: 552].

This was not the only occasion on which state authorities were concerned that preachers might provoke some undesirable consequences. In this light we may also observe some contemporary remarks about the style of individual preachers. The favorite preacher at the Ragusan cathedral, the Franciscan friar Sebastian Slade Dolci, was famous for his learning, clarity of expression, and sonorous voice. There has also been preserved a detailed description of

39 At a diocesan synod in 1729, Archbishop Angelo Franchi asked all clergymen to write sermons as part of their regular exams [SEFEROvić 2012A: 53-54].

40 Even nuns belonged to the same category, as is proven by letters sent to the state authorities, which are practically never written in Latin or in Italian but rather in their native language.

${ }^{41}$ In his descriptions of regular rites at the Dominican church in the first half of the 18 th century, S. M. Cerva could not restrain himself from mentioning the "poor little women" (mulierculae) who devotedly visited every single one of the eighteen altars in the church [Monumenta Congregationis: 98]. 
a performance by the Dominican friar Hyacinth Maria Passati. According to his younger contemporary and member of the same monastery in Dubrovnik, Seraphinus Maria Cerva, Passati was "famous by his gestures and body composure, but above all by his exceptionally clear, pleasant, and strong voice: he did not lack any of those virtues that make a good orator" [CERVA 1977: 157].

Unfortunately, there were preachers who suffered because of physical impediments to successful preaching. For example, many contemporaries believed that the Franciscan friar Angelo Dolci was as learned and gifted as his elder brother, Sebastian, but he was a much weaker preacher due to his stammering [RODE 1914: 96]. The Dominican friar Kalić had a quiet voice and weak breath by nature, but (unlike Angelo Dolci) he was often invited to preach and enjoyed great respect at the pulpit of the Dominican church, due to his austerity and the high quality of his sermons [SKURLA 1873: VI, VIII; SEFEROviĆ 2012B: 108].

We can only speculate as to whether or not secular orators were equal to the religious speakers in their oratorical skills. It was common for a member of the Ragusan patriciate to greet the preacher before his sermons in the cathedral and to give a complimentary speech. Due to the silence of our sources, we cannot establish with certainty the topics of these speeches, but we assume that they were connected with the general topics of the sermons. These patricians always received an appropriate gift in food for their effort, usually a lamb and some delicacies. ${ }^{42}$ It may be possible to connect this custom with the "political preaching," predica della politica, which was settled by the Senate decision in 1782 [SEFEROVIĆ 2012B: 134]. Several samples of similar talks have been preserved in later copies in Ragusan libraries, including speeches by Ragusan clergymen in Italy, especially by the friar Sebastian Slade Dolci, whose speech delivered in Lucca in 1731 for the city council was published [KNEzović 2011: 272]. Preaches were usually praised for their efforts, but there were occasions when they were not spared from severe criticism, coming both from secular and spiritual circles.

\section{The Critics of the Preachers}

Commonly perceived as "masters of human hearts, ${ }^{43}$ preachers enjoyed a unique role in society and, accordingly, had special responsibilities. Nevertheless, the Ragusan public bore witness to various incidents that occurred during their performances. Some of the public reactions were strictly personal: the flock generally disliked the custom of Dominican friar Anthony Bonda, who, in the early 18th century, used to threaten people openly during his sermons,

${ }^{42}$ There are various examples from the 18th and early 19th centuries [Detta, passim].

${ }^{43}$ The expression describes the Ragusan-born Jesuit, Đuro Bašić [GoRTAN 1970: 632-633]. 
pointing at major sinners in the public [CERVA 1975: 100]; his contemporary, fellow Dominican Jerome Philippi, enjoyed the bad reputation of being a "strange" man, because of his untidy attire and irregular habits [IDEM 1977: 143].

Ragusans showed a surprising level of tolerance, however: no preacher was attacked or scorned because of his physical inabilities to perform his task. The critics in this period based their opinions on other things that were in direct relation to the sermons themselves. These were connected both to the message of the sermon (including various theological and political issues) and to its form, that is, to the performance by the preachers. It seems that members of the Mendicant Orders (the most popular preachers) were particularly exposed to severe criticisms.

On the basis of content and style of preaching, the Holy See several times repeated its warnings to Franciscan friars to omit jests and jokes in their sermons (which were, more or less, typical for Baroque oratory), and its letters of complaint about these matters reached the St. Francis' Province in Dubrovnik [SEFEROVIĆ 2008: 84-85]. The basic argument was that preachers were not supposed to entertain but to perform their duty in the most serious way, even when this was contrary to public taste. In the words of a renowned historian from that time, these sermons were not accepted by the wide public unless they were witty, embellished with strange tales, and even making the audience laugh [CERVA 1980: 73].

It is interesting that the same criticisms were addressed to other public speakers, specifically, to those who had to deliver funeral speeches in honor of deceased dignitaries of the Republic. In the beginning of the 19th century, Piarist Francesco Maria Appendini, in his review of the political and cultural history of Dubrovnik entitled Notizie storiche di Ragusa, noticed that funeral speeches were regularly performed until the Great Earthquake. Appendini praised the speakers' serious efforts (these were also recognized by the learned Ragusan public), but then observed that this practice significantly deteriorated from the late 17th century on, with the unnecessary surfeit of "vague Baroque rhetoric" [APPENDINI 1803: 128, 134]. Although the same remark was made by S. M. Cerva, who detested public school teachers as exceptionally bad speakers on similar occasions, claiming that they sometimes produced a completely wrong effect [CERVA 2008: 529], preserved texts do not confirm these harsh opinions. On the contrary, on the basis of many speeches of this kind ${ }^{44}$ we can agree only that speakers seem to have been well prepared and highly motivated to perform their duty well, and that there was really nothing inappropriate in their appearances. Even on those occasions when foreigners were engaged, everything was fine: the public preacher Giovanni

${ }^{44}$ See published texts with Croatian translations and commentaries [BAšIć 1872; SKURLA 1873; SEFEROVIĆ 2012B; IDEM 2015, IDEM 2016A]. 
Stephano Facchinelli, in 1709, was awarded the special honor of giving a laudatory speech on the Feast of St. Blaise, and he got his well-deserved prize afterwards. ${ }^{45}$

However, some curious incidents really did happen during the sermons in the cathedral, and they were related not to jests and similar trivialities, but to politics and to theological subtleties. At least two similar cases were mentioned in the early decades following the Great Earthquake. It was friar Giovanni Crisostomo Bonarrota, the provincial of St. Francis' Province of Dubrovnik, who first claimed in his sermon that Jesus himself had knelt in front of the Devil, when he washed Judas Iscariot's feet on Maundy Thursday. ${ }^{46}$ Any major consequences for the Republic for such an audacious construction, involving a trial in front of the pope himself, were luckily avoided when this unhappy preacher conveniently died just few years later (while his trial process was still being prepared). Another curious theological incident occurred when Dominican friar Salvatore Giorgi, a few years later, provoked an indignant outburst among distinguished listeners who gathered to hear his sermon about the Holy Virgin, during which Giorgi denied the Immaculate Conception. ${ }^{47}$ His biographer, a Dominican friar from the same monastery in Dubrovnik, preserved the honor of his fellow brother by claiming that he justified himself in Rome, and he even added a witty story: when another Franciscan preacher, Dionysius Gigli, became a preacher in the cathedral and tried to attack this erroneous view from the most prestigious city pulpit, by Divine miracle the attacker simply remained speechless and was compelled to withdraw from the pulpit in shame. ${ }^{48}$

However, much more importance in public was given to the political contexts of these sermons. When Sebastian Slade Dolci, speaking in 1760 from the cathedral pulpit, took the liberty of accusing the state authorities by saying that the Senate had squandered money, soldiers, and wisdom, ${ }^{49}$ he was not

${ }^{45}$ His reward included six bottles of wine and four hens [Detta, Vol. 24, f. 80r].

46 This is not only according to the Dominican historiographer [CERVA 1977: 278-280], who was obviously ill disposed towards this prominent Franciscan, but also according to Franciscan sources themselves, even briefly mentioning the entire incident [RODE 1914: 52].

${ }^{47}$ Apparently, Giorgi was luckier than his Franciscan predecessor, because he managed to justify himself in front of the Holy See [CERVA 1980: 73-75]. Perhaps there was also some importance in the fact that Bonarrota was a commoner, while Giorgi was a patrician by birth.

${ }^{48}$ This curious episode is also mentioned by Cerva in Gigli's biography [CERVA 1975: 252-253], but it is not mentioned in other sources. Since both Cerva and Franciscan authors were contemporaries, obviously some of them tried to hide the truth. In his own biography of Gigli, Slade omits this detail and only praises Gigli as great theologian and preacher, someone who prepared more than 300 sermons in Italian and in his native idiom [SLADE 2001: 101].

${ }^{49}$ The former French envoy to Dubrovnik, Alexandre Le Maire, was delighted to include this episode in his report to the French government in 1766 [SEFERović 2012A: 197]. 
allowed to preach in Dubrovnik for the next ten years. Another Franciscan friar, Marin Marincelo, had intervened in a similar way previously, in 1684 [PANTIĆ 1957: 26], and suffered serious consequences: although he was a good theologian and excelled as a diplomatic envoy of the Republic, he never became the bishop of Ston. Until the end of the Republic there were similar attempts to send some political messages from pulpits, but in a more subtle way, especially underlining the unfortunate subordination of the Church to the state. Dominican friar Kalić deliberately mentioned in a sermon three ecclesiastical dignitaries who suffered because they resisted the state: St. Ambrosius, St. John Chrysostom, and St. Thomas Becket [SEFEROvić 2012B: 105]. However, thanks to the preachers' self-imposed discipline and some precautionary steps by the government, no harm was done. There were other means to arouse the public sentiments.

\section{Preachers' Legacy: Books and Advice}

Apart from the power of their words, ever since the Middle Ages "preachers demanded tangible signs of the spiritual regeneration they effected and the mission often ended with an auto-da-fé in which games of chance and female frippery were burned on a pyre" [VAuCHEz 1997: 331]. Thanks to the common sense and careful surveillance by the state authorities, similar incidents never took place in Dubrovnik and, what is especially important, there were no outbursts of violence..$^{50}$ Yet it cannot be denied that some preachers were more passionate than others. During the second visit of the Jesuit Giovanni Battista Cancellotti to Dubrovnik, in 1718-1719, when he preached in the church of St. Blaise, many books were burned and destroyed under the crucifix and there were also many reconciliations among devoted believers, to the benefit of the entire community [VANINO 1937: 50]. Apart from morning sermons in the cathedral, Cancellotti held oratories in the church of St. Blaise for eight evenings consecutively, during which he also whipped himself. ${ }^{51}$ Dominican friar Kalić was less radical when, in 1784, he described the plague epidemic as the finger of God against extravagance in the city, but his sermons were published at state expense, which was a unique case [SKURLA 1873: VII]. In the same year, 1784, there occurred the last major decision by the state authorities regarding sermons: the Senate decided that all sermons must be handed over in written form [Cons. Rog., Vol. 192, f. 214r].

50 In 1724 the state authorities ordered the first large-scale confiscation and destruction of the books of the Talmud, but this remained an isolated incident, provoked by the Senate's desire to indulge the archbishop [SEFEROVIĆ 2006: 187-188].

51 These oratories were held in the city protector's church until 1725, and subsequently in the Jesuit College church [VAnino 1987: 106]. According to the Book of Annals of the Jesuit College in Dubrovnik, it was Cancellotti himself who introduced these oratories, and the Jesuits subsequently retained them until 1771 [IDEM 1937: 166]. 
Although it had never become a custom to sell sermons after the preaching cycle, sermons in the 18th century still put their stamp on both spiritual and public life [LonzA 2009: 347-348]. However, things began to change at the beginning of the 19th century, when there appeared a general lack of discipline. This phenomenon may have been related to the quick penetration of new ideas brought by the Enlightenment and the French Revolution, ${ }^{52}$ or it may be connected to the fact that the Republic of Dubrovnik was in its final decay. The situation became so intolerable at the beginning of the 19th century that the state authorities were even compelled to proclaim, on 22 May 1803, that all coffee shops in the city must be closed during the holy mass in the cathedral [Cons. Min., Vol. 114, f. 110r]. They were not even sure anymore who would preach in the cathedral. When canon Raphael Radeglia was granted this honor on 26 February 1803 for Advent of the following year, the Small Council informed him that this period was already reserved for another preacher and that he would preach on the first available subsequent occasion. He simply served as a backup in case the invited preacher failed to come [ibid., f. 84r].

But it was during this period that preachers in smaller churches even more closely followed the reactions of their flock, and tried to adapt their sermons in accordance with general expectations. By the end of the 17th century, Franciscan friar Vital Andriassi wrote a treatise called Viridarium (Spiritual garden), a collection of disputes on moral theology, in which he discussed some concrete problems of preaching. In the chapter entitled "The Problem with Those Who Fall Asleep at Sermons" (Problema de dormientibus concionis tempore), Andriassi noted that at sermons, men fall asleep more often than women. Probably based on his own rich experience, he concluded that there were two likely reasons for this: first, that women are naturally more shy than men in public, and second, that preachers sometimes attract attention from their public not only by the power of their word but also by their own appearance [SEFEROvIĆ 2013: 105].

These remarks offer an interesting insight into the psychology of the flock. Although it practically never happened that public sermons (especially in the cathedral) induced believers to mass confessions (this did not happen even during those tragic days of the Great Earthquake), or to change their erroneous, sinful daily routine, our sources claim that there were some successful sermons against usury. These were given by Dominican friar Raimund Sey in the Dominican church at the end of the 18th century, when apparently the Jews themselves were touched and decided to forgive their debtors [SEFEROVIĆ 2008: 111].

52 There were various political factions within the Ragusan patriciate at the end of the 18th century, and these divisions became visible even in public oratory [SEFERović 2015: 323-325]. 
There may be new discoveries in light of the abundant material that has been preserved. On well-stocked shelves in Dubrovnik's archives and libraries, we discover hundreds of sermons, written in three main languages: Latin, Italian, and Croatian. Due to the lack of a complete catalogue of these texts, ${ }^{53}$ the researcher is compelled to turn to general catalogues of the libraries. Today there are preserved manuscripts with copies of sermons, written down in the 19th century, ${ }^{54}$ during the period of the Austrian government. ${ }^{55}$ From the second part of the 18th century, there appeared several collections of sermons in printed form. Their authors were local preachers-Franciscans, Jesuits, and Dominicans-who published their sermons, written in their native language, even in Venice. ${ }^{56}$ Sermons thus acquired a new function, becoming textbooks for young clergymen and for students of preaching and rhetoric in general.

In the period after the Great Earthquake until the beginning of the 19th century, there appeared several handbooks for would-be preachers. In comparison to Italy, which served as a model in so many features of local spiritual life, their number is surprisingly small..$^{57}$ The explanation is that various sermons shared a common pattern and that there was also, in general terms, quite a low level of education in Dubrovnik. Starting with an appropriate sentence from the New Testament, usually either related to a feast that was celebrated on a particular day or in direct connection with the long preaching cycles in Advent and Lent, sermons would end with blessings of the gathered flock or with an invitation to join in common prayer or to hear confessions.

Apart from brilliant rhetoricians and preachers such as the Jesuit Ivan Luccari, who, in the second part of the 17th century, excelled as a teacher of rhetoric at the College in Rome and enjoyed great respect among his contemporaries [CERVA 1977: 233-234; SLADE 2001: 117], similar attempts by his colleagues in Dubrovnik brought little success. Obviously written under Luccari's

53 The author of this paper intends to prepare a catalogue in his forthcoming book about preachers in Dubrovnik, spanning the period from the Middle Ages until the end of the Republic of Dubrovnik, in the early 19th century.

${ }^{54}$ Many Latin texts by Ragusan authors have been preserved in this way. Today they are kept mostly in the library of the St. Francis' Monastery and in the Scientific Library.

55 Since the disappearance of the Republic, political changes followed the changes in ecclesiastical organization, as the former Archbishopric and Metropolitan See of Dubrovnik was reduced to a mere bishopric in 1828, a status it has retained up to the present day.

56 While Kalić and Zuzzeri got their sermons published in Dubrovnik, Franciscan friar Vital Andriassi published a collection of his Lenten sermons in Venice in 1661, and, in the same city in 1679, he published a collection of his Advent sermons [SLADE 2001: 145]. We may perceive them as a continuation of the practice established in the 16th century, when Dominican friar Clemens Ragnina prepared the first edition of his huge collection, entitled Quodlibet declamatorium (Venice, 1541) [SEFEROvić 2016B: 208].

57 Between the 1570 s and the 18 th century, over 1,200 works on sacred rhetoric appeared [NORMAN 2001: 138]. 
influence by an anonymous Jesuit, there appeared the Trattato della Eloquenza Ecclesiastica, a manuscript with sixty numbered pages..$^{58}$ It was addressed to pupils in the seminary and to would-be parish priests, but its real purpose was to serve for education in the Jesuit College, extolling Paolo Segneri as a great model. The treatise heavily relied on Cicero, both in its approach to the public and its advice regarding behavior and appropriate gestures by the preacher. It also included some advice about moral theology, logic, and history in general. Since the anonymous author of this treatise instructed young preachers to follow Cicero as their ideal orator, he obviously neglected the advice from the Holy See stating that preachers should restrain themselves from going too far with rhetorical embellishments in their sermons.

Another example of a similar kind has been preserved in the library of the St. Francis' Monastery in Dubrovnik, where many books and manuscripts from the temporarily closed Jesuit College found their place. In a work with the title Formulae oratoriae, there is another proof of strong influence from Cicero on the practice of local preachers, which is surprising coming from such a late period [Formulae oratoriae]. In this careful selection of sentences from various speeches by Cicero, divided into thirty-two separate elements, a young cleric had a reliable and thorough guide to becoming a good preacher. Unfortunately, this text was already outdated and thus was not effective: written by an anonymous author in the 18th century, when Latin was not in regular use even at the most prestigious pulpits in Dubrovnik, and especially not in peripheral, distant churches, this manual had only a theoretical, and not a practical, purpose.

This is yet another proof that preachers in the sunset of the Republic of Dubrovnik played merely a formal role. It was only important to maintain the tradition of giving sermons. After all, this was one of the key features of the Republic of Dubrovnik and its distinct legacy.

\section{Concluding Remarks and Possibilities for Further Research}

Preaching was perceived as one of the main elements in spiritual culture, with a vital role in the everyday life of all Ragusan citizens, regardless of their social status. In the struggle for survival after the Great Earthquake of 1667 and the subsequent political changes that finally brought the Republic of Dubrovnik to its end at the beginning of the 19th century, public authorities used every opportunity to consolidate the state. In this agenda, sermons were a particularly important tool, with two separate purposes: in smaller churches, to keep the commoners loyal and devoted to the ruling class of patricians within the existing political framework of the old Republic, and in the cathedral, to preserve a tradition of inviting foreign preachers for formal reasons, to contribute

58 Today kept in the Scientific Library in Dubrovnik, manuscript No. 835. 
to the international reputation of the state. The multilingual environment in Dubrovnik, where sermons were given in Latin, Italian, and Croatian, significantly facilitated this task for foreign clerics, usually members of various religious orders coming from Italy at the invitation and expense of the state.

Since the large amount of primary sources (both of secular and of ecclesiastical origin) is still unexplored, the first task of the present research was to establish the background of the preachers and the direct steps taken by the government to control their activity, including the variety of laws brought at regular sessions of the Senate and the Small Council of the Republic. A more complete insight into this complex mosaic will depend on subsequent analyses of the sermons themselves and of manuals for would-be preachers, preserved either in manuscripts or in printed form.

\section{Bibliography}

\section{Primary Sources}

State Archives of Dubrovnik

Acta et diplomata

Acta et Diplomata, series 76, 18th century.

Cons. Min.

Acta Consilii Minoris, series 5.

Cons. Rog. Acta Consilii Rogatorum, series 3.

Detta

Detta, series 6.

Lettere di ponente Litterae et epistulae ponentis, series 27.6.

Library of St. Dominic's Monastery in Dubrovnik

Monumenta Congregationis Monumenta Congregationis Sancti Dominici de Ragusio Ordinis Fratrum Praedicatorum edita a fratre Seraphino Maria Cerva. Seculum primum ab anno MCCXXV ad annum MCCCXXIV, Ms. no. 34-IX-9/1.

\section{Library of St. Francis' Monastery in Dubrovnik}

Formulae oratoriae Forumulae oratoriae, MS No. 139.

Orationes Latinae

Orationes Latinae civium Rhacusinorum Rhacusii habitae, MS No. 243.

Sermoni di passione

Sermoni di passione, MS No. 173.

Scientific Library in Dubrovnik

Predica

Predica XXI. Venerdì dopo la 3.a Domenica di Quaresima. Della divina misericordia, MS No. 464/2. 


\section{Published Sources}

CERVA 1975

CERVA S. M., Bibliotheca Ragusina in qua Ragusini scriptores eorumque gesta et scripta recensentur, 1, S. KRAsić, ed., Zagreb, 1975. 1977

CERVA S. M., Bibliotheca Ragusina in qua Ragusini scriptores eorumque gesta et scripta recensentur, 2, S. KRAsić, ed., Zagreb, 1977. 1980

CERVA S. M., Bibliotheca Ragusina in qua Ragusini scriptores eorumque gesta et scripta recensentur, 3, S. KRAsić, ed., Zagreb, 1980. 2008

CERva S. M., Prolegomena in Sacram metropolim Ragusinam, R. SEFERović, ed., Zagreb, Dubrovnik, 2008. 2012

CERva S. M., Prolegomena za Svetu dubrovačku metropoliju, R. SEFERović, ed., Zagreb, Dubrovnik, 2012.

DE DIVERSIS 2004

De Diversis F., Opis slavnoga grada Dubrovnika, Z. JANEKović-RöMER, ed., Zagreb, 2004.

RAZZI 2011

Razzi S., Povijest Dubrovnika, S. Krasić, ed., Dubrovnik, 2011.

RODE 1914

Benvenutus Rode P., ed., Necrologium Fratrum Minorum de Observantia Provinciae S. Francisci Ragusii, Ad Claras Aquas (Quaracchi), 1914.

SLADE 2001

Slade S., Fasti litterario-Ragusini. Dubrovačka književna kronika, P. KnEzović, ed., Zagreb, 2001.

SOPTA 2006

Sopta J., ed., Spisi Franjevačke provincije u Dubrovniku: analitički inventar, Dubrovnik, 2006.

VANINO 1937

VAnino M., ed, Chronicon Collegii Ragusini 1559-1764, Sarajevo, 1937.

\section{References}

\section{APPENDINI 1803}

ApPendini F. M., Notizie istorico-critiche sulle Antichità. Storia e Letteratura de’ Ragusei, 2, Ragusa, 1803.

\section{BAŠIĆ 1872}

BAŠIĆ GJ., “Život Bernarda Cuceri, družbe Isusove,” in: J. RIEGER, ed., Besjede duhovne Bernarda Cucera, Dubrovčanina, Zagreb, 1872, IX-XIX.

BRLEK 1952

BRLEK M., Rukopisi knjižnice samostana Male braće u Dubrovniku, Zagreb, 1952.

Ćosıć 1996

Ćosıć S., "Administrativna struktura i plaće službenika Dubrovačke Republike (1700-1808.)," Radovi Zavoda za povijesne znanosti HAZU u Zadru, 38, 1996, 129-156.

ĆOSIĆ, VEKARIĆ 2005

ĆOSIĆ S., VEKARIĆ N., Dubrovačka vlastela između roda i države: salamankezi i sorbonezi, Zagreb, Dubrovnik, 2005. 


\section{GORTAN 1970}

Gortan V., "Đuro Ferić. Georgius Ferrich (1739-1820)," in: V. GorTAN, V. VRatović, ed., Hrvatski latinisti, 2, Zagreb, 1970, 611-697.

JANEKOVIĆ-RÖMER 2003

JANEKOVIĆ-RÖMER Z., Višegradski ugovor temelj Dubrovačke Republike, Zagreb, 2003.

2015

JANeKović-Römer Z., The Frame of Freedom: The Nobility of Dubrovnik between the Middle Ages and Humanism, Zagreb, Dubrovnik, 2015.

KNEZović 2011

Knezović P., "Sebastijan Slade," in: S. SLADE, Fasti litterario-Ragusini. Dubrovačka književna kronika, P. KNeZović, ed., Zagreb, 2001, 271-276.

KREKIĆ 2007

KREKIĆ B., "Dubrovnik and Venice in the Thirteenth and Fourteenth Century: A Short Survey," in: IDEM, Unequal Rivals: Essays on Relations between Dubrovnik and Venice in the Thirteenth and Fourteenth Centuries, Zagreb, Dubrovnik, 2007, 9-46.

KunČEvić 2012

KuNČEvić L., "Dubrovačka slika Venecije i venecijanska slika Dubrovnika u ranom novom vijeku," Anali Zavoda za povijesne znanosti HAZU u Dubrovniku, 50, 2012, 9-37.

LASIĆ 2001

LASIĆ S., "Crkvene bratovštine u nadbiskupiji s posebnim osvrtom na 'Popovski zbor'," in: Ž. Puljić, N. A. ANčić, ed., Tisuću godina uspostave dubrovačke nad(biskupije), Split, Dubrovnik, 2001, 687-701.

LONZA 2009

LonZa N., Kazalište vlasti. Ceremonijal i državni blagdani Dubrovačke Republike u 17. i 18. stoljeću, Zagreb, Dubrovnik, 2009.

NORMAN 2001

Norman C. E., "The Social History of Preaching: Italy," in: L. TAYLOR, ed., Preachers and People in the Reformations and Early Modern Period, Leiden, Boston, Köln, 2001, 125-191.

PANTIĆ 1957

Pantić M., Sebastijan Slade-Dolči, dubrovački biograf XVIII veka, Beograd, 1957.

RošČIĆ 2012

Roščić N. M., Sv. Frane brodolomac. Dolazak sv. Frane u Hrvatsku 1212, Zagreb, Split, 2012.

SAMARDŽIĆ 1960

SAMARDŽIĆ R., Borba Dubrovnika za opstanak posle velikog zemljotresa $1667 \mathrm{~g}$. Arhivska građa (1667-1670), Beograd, 1960.

$-1983$

SAMARDŽIĆ R., Veliki vek Dubrovnika, 2nd ed., Beograd, 1983.

SEFEROVIĆ 2006

SEFEROvić R., “Dubrovački teolozi o židovskoj zajednici u prvoj polovici 18. stoljeća,” Anali Zavoda za povijesne znanosti HAZU u Dubrovniku, 44, 2006, 139-188.

2008

SEFEROVIĆ R., "Adventski i korizmeni propovjednici u dubrovačkoj katedrali u 18. stoljeću," Anali Zavoda za povijesne znanosti HAZU u Dubrovniku, 46, 2008, 81-124.

2010

SEFEROvić R., "Dubia et consulta: mišljenja državnih teologa Dubrovačke Republike u 17. i 18. stoljeću”, Anali Zavoda za povijesne znanosti HAZU u Dubrovniku, 48, 2010, 243-300. 
2011

SefErović R., "Fantazija povijesti: legenda biskupa Antuna Primija o kralju Pavlimiru," Anali

Zavoda za povijesne znanosti HAZU u Dubrovniku, 49, 2011, 133-178. 2012A

SefERović R., "Crkva iza Dvora. Kroz povijest dubrovačke Crkve 18. stoljeća uz pratnju Serafina Marije Cerve,” in: S. M. CERva, Prolegomena za Svetu dubrovačku metropoliju,

R. SEFERović, ed., Zagreb, Dubrovnik, 2012, 9-253. 2012B

SEFEROvić R., “O nadbiskupu Lazzariju uz retorički ornat”, Anali Zavoda za povijesne znanosti HAZU u Dubrovniku, 50, 2012, 91-161. 2013

SEFEROvić R., “Moralnoteološka promišljanja klerika u baroknom Dubrovniku," Croatica Christiana Periodica, 72, 2013, 85-117. 2014

Seferović R., “Sveta godina 1550. u Dubrovniku: svetkovine, prijepori i pojedinci,” Anali Zavoda za povijesne znanosti HAZU u Dubrovniku, 52/1, 2014, 51-87. 2015

Seferović R., “Politička retorika Francesca Marije Appendinija s kraja Republike,” Anali Zavoda za povijesne znanosti HAZU u Dubrovniku, 53/2, 2015, 311-349. 2016A

SEFERović R., "Isusovac Antonio Morcelli, nesuđeni nadbiskup s kraja Republike," Anali Zavoda za povijesne znanosti HAZU u Dubrovniku, 54/2, 2016, 263-291. 2016в

SEFEROvić R., "Svjetlo riječi, sjena vlasti: kasnorenesansni propovjednici u dubrovačkoj katedrali,” in: Z. BlažEvić, L. Plejıć Poje, ed., Tridentska baština. Katolička obnova i konfesionalizacija u hrvatskim zemljama, Zagreb, 2016, 193-209.

SKURLA 1873

SKuRla S., “O. Arkangjeo Kalić,” in: IDEM, ed., O. Arkangjela Kalića Korizmene propovijedi i besjede za različite svečanosti i prigode, Dubrovnik, 1873, V-XIII.

ŠKUNCA 2010

ŠKUnCA S. J., "Putovanje kroz povijest," in: I. Fisković, ed., Milost susreta. Umjetnička baština Franjevačke provincije Sv. Jeronima, Zagreb, 14-27.

VANINO 1987

VANINO M., Isusovci i hrvatski narod, 2, Zagreb, 1987.

VAUCHEZ 1997

Vauchez A., “The Saint,” in: J. Le Goff, ed., The Medieval World, London, 1997, 313-345.

VEKARIĆ 2011

VEKARIĆ N., Vlastela grada Dubrovnika, 1. Korijeni, struktura i razvoj dubrovačkog plemstva, Zagreb, Dubrovnik, 2011.

VoJNOVIĆ 1912

VoJnović L., "Prva smrt Dubrovnika (6. aprila 1667)," Letopis Matice srpske, 86, 1912, 52-69.

\section{Acknowledgements}

I wish to express my sincere gratitude to Dr. Ekaterina I. Kislova, from the Moscow State University Philology Department, and to Dr. Denis A. Sdvizkov, from the German Historical Institute in Moscow, for inviting me to the round table on Sermons in Religious and Cultural Politics and Practice in Russia and Europe in the 18th-early 19th centuries, organized by the German Historical Institute in Moscow on 26 and 27 August 2016, where I read the first draft of this paper and discussed it with other participants, whose efforts helped me to improve it significantly. 
Relja Seferović, Ph.D.

Zavod za povijesne znanosti HAZU u Dubrovniku Lapadska obala 6 20000 Dubrovnik Republika Hrvatska / Republic of Croatia rseferovic@hazu.hr

Received March 9, 2017 